\title{
A priori aggregation multicriteria optimization of family business vitality through Likert scaling with price evaluation
}

\author{
Lucia Orlovova ${ }^{1, *}$, and Lukas Pospisil ${ }^{2}$ \\ ${ }^{1}$ VSB-TU Ostrava, Faculty of Economics, Department of Management, Sokolska trida 33, 70200 \\ Ostrava, Czech Republic \\ ${ }^{2}$ VSB-TU Ostrava, Faculty of Civil Engineering, Department of Mathematics, Ludvika Podeste \\ 1875/17, 70800 Ostrava, Czech Republic
}

\begin{abstract}
.
Research background: In this work, we are dealing with the problem of the optimal decision for increasing the vitality of family business. This type of business is the global topic since the companies owned by the family members with the equity capital shared with family are widespread all around the world and belongs to the one of the most popular types. The field of family businesses is characterized by specific properties and therefore, we suggest the measure of the vitality based on Likert scaling. The variants of the possible improvement are weighted by the required time and money.

Purpose of the article: By solving the presented corresponding optimization problem, we manage to obtain optimal investment to the improvement of vitality measured by Likert scaling. The proposed methodology aims to avoid the influence of emotional aspect of decision making and rather find the optimality based on financial and time costs.

Methods: In our contribution, we propose and compare two different formulations: the problem with constrained budget and the multicriteria formulation of the problem of the vitality maximization with costs minimization using the aggregation with a priori known coefficients. The corresponding integer linear programming problem with linear constraints is solved in Microsoft Excel.
\end{abstract}

Findings \& Value added: We examine, compare, and discuss the proposed methodologies on the selected practical benchmark.

Keywords: aggregation; family business; Likert scaling; multicriteria optimization; vitality

JEL Classification: $C 39 ; D 24 ; M 21$

${ }^{*}$ Corresponding author: lucia.orlovova@vsb.cz 


\section{Introduction}

In our research, we are interested in qualitative and quantitative evaluation methods, which are key to evaluate the performance of businesses. This paper presents the method for optimal decision in the problem of improving the vitality of family business. The quantification already exists for this area using query methods, such as Likert scaling. In this case, the respondent evaluates the significance of individual criteria from one to five, and based on the results, it is possible to quantify the degree of vitality of the business, expressed by one fair value, using a weighted sum.

However, a family business has its specifics. Especially because the decision criterion for the further development of the company is not primarily profit, as is the case with standard forms of business, but also the goals associated with the family. Family members are usually involved in the functioning of the company as well as in deciding on further development. The choice of the optimal decision can therefore be complicated due to the impossibility of formulating exactly the criteria of the optimal decision.

The basic question is whether it is possible to increase this number, and thereby increase the vitality of the business. Of course, the easiest way is to focus on all criteria and achieve the maximum possible value. However, in practice any such improvement requires both time and financial demands, which are simply not available. The problem is optimization - how to maximally increase the vitality of the business at the lowest possible cost.

In this paper, we solve the problem of optimal decision-making. The individual variants of improvement are evaluated by time and price. We formulate the corresponding mathematical problem, first by limiting the total budget that can be spent. We solve the problem using the Simplex algorithm by implementing our approach in a Microsoft Excel.

Subsequently, we reformulate the problem using a model of multicriteria decision. We assume that the user defines the aggregation coefficients in advance (a priori), i.e., user defines whether it is more important to maximize the vitality of the business or minimize the costs.

In Section 2, we describe the background - we discuss the problematics of family business, introduce Likert scaling and weighted sum to define the degree of vitality. The section concludes with a brief introduction to the issue of multicriteria decision making and the derivation of corresponding mathematical model. Section 3 focuses on solving a specific example, on which we test the presented methodology. Finally, in Section 4, we summarize the achieved results and discuss further development.

\section{Description and mathematical formulation of methods}

This part of the paper clarifies the concepts of family business, Likert scaling, business vitality, multicriteria decision making. At the end of this section, we present the derivation of a mathematical model.

\subsection{Family business}

According to [1], a family business is not a standard economic category. The family business is owned by an individual with family facilities, or directly by the family. The strategic influence of the owner's family on the further direction of the business is significant. The legal status of a family business is not decisive, it can be a trade, a public trading company, a limited partnership, a limited liability company, or a joint stock company. In the case of a joint-stock company, it is essential that the family has a decisive influence over the business and does not even have to hold a majority shareholding. The family business is attended by 
several family generations, who participate in its work, and manage the business in a decisive way.

The main criterion for determining whether a business is family or not is its ownership. It is also about engaging family members in the business; in theory they do not even have to participate in their own business. In a family business, the leading generation reinvests a substantial part of the profit, so the family business has considerable potential for development. On the other hand, development can be hampered by an "autocratic leader", usually the father - as the founder, or a large number of family members struggling for influence in the business $[1,2]$.

A necessary condition for defining a family business is the family's share in equity. The family has a decisive and determining influence, i.e. it completely dominates in one of the determining factors, which are either equity or membership in the statutory body [3 - 6].

In the Czech Republic, it was not until 2019 that the term family business was defined. "A family business is a business in which at least two members of one family participate in their work or property, and at least one of the members of this family holds a trade license or other similar authorization, or is authorized to conduct business for another reason. For the purposes of a family business, members of the same family are considered to be spouses or partners working together, or with at least one of the spouses or partners and their relatives up to the third degree, or also direct relatives or siblings. If there is a person among them who is not fully legally responsible, he is represented in the vote by the legal representative, if he is a minor, otherwise the guardian." [7].

The European Commission classifies family businesses as companies or businesses in which the majority of the decision-making rights are owned by the founder or transferee, or their spouses, children, parents, grandchildren, or where the majority of the decision-making rights are direct or indirect, the family business is the classification if at least one family representative or relative is formally involved in the management of the business, or in the case of publicly traded companies, their founder or acquirer, or their family or descendants own at least $25 \%$ of the decision-making rights $[8,9]$.

An important factor that distinguishes a family business from a non-family business is the existence of family-related goals. Family businesses pursue not only economic goals, such as profit maximization, profitability, or market values, but also non-economic goals they provide employment to family members, ensure financial independence and security, integrate family values into the business, maintain control of the business within the family, and ensure a positive corporate reputation. Family businesses place more emphasis on socioemotional wealth than non-family ones and attach more importance to them than to financial goals $[8,10,11]$. It is clear from the above that in the case of family businesses, decisionmaking is not only influenced by relevant factors, and therefore the only way to propose the optimal solution is to consider all options and decide on the basis of optimization analysis. In this project, we focus on improving the vitality of the business. One of the ways to quantify the vitality of the business is by means of Likert scaling, where shortcomings can be identified, using a predefined list of criteria [12 - 15].

\subsection{Likert scaling}

This quantification method is used to determine the degree of agreement or disagreement with the statement with which the respondents of the research are confronted. Scaling should be polarized from disagreement to agreement, with an odd number of degrees. The formulation of the statement must be carefully selected: the result should be a model with, ideally, 10 to 15 items that have a high t-value. Based on the selected items, it is appropriate to create a set of statements in which positive and negative opinions alternate. This diversity 
prevents the respondent from falling into a stereotype $[12,13]$. Using Likert scaling, for example, the degree of vitality of a family business may be quantified.

\subsection{Vitality of the company}

In the case of a family business, the vitality is the ability to pass on a generational business system based on quality relationships [16]. The theory of vitality is built on four statements; namely that everything arises on the principle of continuity, disorder, imperfection, and reality. The priority is a system composed of elements and relationships that are key to the functioning of the system. When evaluating the system, it is necessary to determine both its condition and the ability to implement changes. When evaluating the condition of the system, we deal with efficiency and effectiveness. Assessing the ability to change means addressing issues of system stability and development. Vitality varies in different companies, and in order to improve it, it is necessary to define weaknesses and limitations at the beginning. Vitality is the state of health of a family business with the potential for growth and the ability to face challenges $[17,18]$.

The tool for assessing the vitality of a family business is the analysis of strengths and weaknesses, in the range of points from 1 to 5, using Likert scaling. Qualitative evaluation of the vitality of the internal environment of a family business consists of 3 areas: namely administrative-psychological-legal, managerial-strategic management of processes in family business and management, financial management of the company and the family as a complex. The analysis of the external environment of a family business is divided into a macro-environment and a micro-environment. When evaluating the macro-environment, the following influences are examined - demographic, political, legislative, socio-cultural, geographical, technological, economic, and ecological, with evaluation by means of PEST analysis, or its extension. To evaluate the microenvironment, the following criteria are evaluated: partners, customers, competitors, and the public [18].

In this paper, we are using criteria in three areas and in each of them, 10 criteria of specific properties are evaluated. The aim of the first area of the Administrative-Psychological and Legal Area is to define family business from the point of view of administrative and legal aspects in the Czech Republic, and to define its specifics. Specifics are given by the entry of family relationships into the business process from the establishment, initiation, planning, management, to the generational exchange. An unmistakable feature of family business is a greater interest in the development of the community in which they live and do business [18]. The aim of the second part of the Management Area is to define the specifics of family business in terms of managerial functions and roles. These are development plans, taking into account the differences of family business, addressing the relationship between family and non-family members, and social responsibility. The aim of the third part of the Economic and Financial Area is to define the rules for the balance between the interests of the family and the family business in the field of finance. The strategic financial plan affects the economic results of the business, and subsequently, the standard of living of the whole family [18].

To measure the property of a given parameter, exactly one evaluation from the set $H=$ $1,2,3,4,5$ is always used. The values of the individual criteria are denoted by $x_{j, k} \in H$, where $j \in\{1, \ldots, J\}$ is the index of areas, $J \in N$ is the number of areas, and $k \in\{1, \ldots, K\}$ are indexes of individual areas, $K \in N$ is the number of criteria in each individual area (we assume that there are the same number of criteria in each area). Through an anonymous survey, the authors of [18] determined the weight of the individual criteria, using the relative frequency for the individual criteria of the given areas

$$
\alpha_{j, k}=\frac{\sum_{i=1}^{n} x_{j, k, i}}{\sum_{i=1}^{n} \sum_{k_{2}=1}^{K} x_{j, k_{2}, i}},
$$


where the values are calculated over all $n$ respondents (third index values $x_{j, k, i}$ ). Obviously, the weights calculated by (1) satisfy

$$
\alpha_{j, k} \in[0,1], \sum_{k=1}^{K} \alpha_{j, k}=1 .
$$

The so-called the resulting benefit of the enterprise can be determined according to a weighted sum

$$
u(x)=\sum_{j=1}^{J} \sum_{k=1}^{K} \alpha_{j, k} x_{j, k} .
$$

Since the weights form the coefficients of the convex combination, then obviously

$$
u: H^{J K} \rightarrow[J \min H, J \max H] \text {. }
$$

Therefore, in our case of three areas, the minimum benefit we can achieve is 3 , and the maximum 15 .

\subsection{Multicriteria decision analysis}

Multicriteria decision analysis is dealing with the modelling of the decision situations, where we are dealing with the $P$ multiple criteria using which we have to choose optimal option from the set of $M$ possible decisions. The aim of the analysis is to find the decision, which is optimal subject to all defined criteria [19 - 21].

In our case, the aim is to increase the vitality of family business, which has been evaluated using the Likert scaling. Since this analysis reveals the shortcomings, which can be eliminated for increasing the vitality, it is clear to which areas we have to focus. However, none of these eliminations is for free; we have to invest both of time and finances and therefore it is hard to determine optimal decision directly from possible options. In this paper, we are solving the problem using optimal decision based on solving the corresponding multicriteria optimization problem - we maximize the benefit and minimize the investments and time consumption.

The first step of multicriteria analysis is the assessment of the criteria weights. This information is used for setting the preferences between variants with respect to the goals of the analysis. After the setting the weights of the criteria, we have a chance to find the compromise solution. This solution is dependent on the preferences, which we choose a priori. One of the most popular methods is the aggregation of criterial functions [19, 20].

The aggregation of criterial functions is based on the synthesis of all objective criterial functions using the suitable operator into one objective function. This operation has to be performed in a such a way that none of the criteria will be distorted, highlighted or weakened, but in the same time there should be a possibility for increasing or decreasing the preferences of criteria. In our case, we are using the convex linear combination of criteria. All criteria has a weights $\beta_{1}, \beta_{2}, \ldots, \beta_{P}$, which define the priorities. We set these weights from interval $[0,1]$ a priori in a such way that

$$
\sum_{p=1}^{P} \beta_{p}=1
$$

Since these weights are normed, the corresponding linear combination and convex. The aggregated criterial function has a form

$$
F(x)=\sum_{p=1}^{P} \beta_{p} f_{p}(x) .
$$

The original optimization problems $f_{p} \rightarrow \max$, where $x \in \Omega_{p}$ are aggregated into 


$$
F(x) \rightarrow \max .
$$

with respect to original constraints from the optimization problems

$$
x \in \Omega=\bigcap_{p=1}^{P} \Omega_{p} .
$$

Usually, the aggregation of completely heterogeneous criteria does not have practical interpretability. It is only the auxiliary criteria, which is used only for finding the compromise decision. The true criteria values have to be recomputed after the solving the aggregated problem, or they have to be included into model as a special type of constraints $[19,20]$.

\subsection{The development of mathematical model}

Let us consider a vitality of the specific company, which has been evaluated by Likert scaling. The overall vitality can be computed using the weighted sum of the values of individual criteria, while the values of weights were determined using (3) by analysing several selected companies. The goal is to increase the vitality of the company by increasing the value of some criteria. Let $y_{k}$ be a new value of $\mathrm{k}$-th criteria. Then new (optimally increased) values can be obtained solving the optimization problem

This problem has trivial solution

$$
\hat{y}=\arg \max u(y) \text {. }
$$

$$
\forall j \in 1, \ldots, J \forall k \in 1, \ldots, K: \hat{y}_{j, k}=\max H .
$$

Let us assume that the improvements of criteria have defined the price for unit improvement and we have only limited budget. Therefore, the improvement of all criteria into the largest possible value is not always possible and the trivial solution (10) is not always possible to achieve.

In our analysis, we denote the price for unit improvement $c_{j, k} \in R^{+}$and the time consumption for unit improvement $t_{j, k} \in R^{+}$. Let $C \in R^{+}$and $T \in R^{+}$denote the overall sum of available financial and time budget. Since we suppose the change of criteria from original value $x_{j, k}$ to new value $y_{j, k}$ and the prices for the unit improvement, the overall prices for the improvement of specific criteria are given by the values $c_{j, k}\left(y_{j, k}-x_{j, k}\right)$ and $t_{j, k}\left(y_{j, k}-x_{j, k}\right)$. To ensure that the budgets will be not exceeded, we sum the prices of all improvements and the constraints are given by

$$
\begin{aligned}
& c(y) \leq C, \text { where } c(y)=\sum_{j=1}^{J} \sum_{k=1}^{K} c_{j, k}\left(y_{j, k}-x_{j, k}\right) \\
& t(y) \leq T, \text { where } t(y)=\sum_{j=1}^{J} \sum_{k=1}^{K} t_{j, k}\left(y_{j, k}-x_{j, k}\right)
\end{aligned}
$$

The optimal new criteria values with budget constraints are given by the solution of integer linear optimization problem (9) with constraints (11), (12), and

$$
\text { (i.e., } y_{j, k} \in H \text { ) and }
$$

$$
\min H \leq y_{j, k} \leq \max H, j=1, \ldots, J, k=1, \ldots, K
$$

$$
y_{j, k} \geq x_{j, k}, j=1, \ldots, J, k=1, \ldots, K,
$$

i.e., the new values are larger or equal to original values - there is not a possibility to "sell" values.

\section{The solution of decision problem using the model}

In this chapter, we are dealing with the solution of the decision problem with constrained budget and afterwards, using the aggregation. 


\subsection{Problem with constrained budget}

For the demonstration of the proposed methodology, we use the data presented in [11]. In this publication, the weights $\alpha_{j, k}$ are computed from 30 companies. For the design of improvement remedies, we propose the improvements with corresponding time and price consumption, see Table 1. For example, if we like to increase the value of criteria 1.9, it would cost 2 hours and $5000 \mathrm{CZK}$.

Table 1. The part of used data: criteria, actual value in Likert scaling, the weight used for the computation of benefit, the proposed improvement with the price. In total, we have 30 different criteria.

\begin{tabular}{|c|c|c|c|c|c|c|}
\hline $\begin{array}{l}\dot{\bar{D}} \\
\stackrel{\Xi}{\Xi} \\
\bar{Z}\end{array}$ & Description & $\stackrel{0}{\frac{0}{\pi}}$ & $\begin{array}{l}\frac{\overrightarrow{7}}{600} \\
\frac{.00}{0} \\
3\end{array}$ & Improvement & $\underset{\Xi}{\varrho}$ &.$\stackrel{\mathscr{U}}{=}$ \\
\hline 1.1 & $\begin{array}{l}\text { The company has defined "constitution": } \\
\text { relationship between employees, code of } \\
\text { conduct, company values }\end{array}$ & 1 & 0,07 & $\begin{array}{l}\text { The definition of the } \\
\text { rules during family } \\
\text { meeting }\end{array}$ & 8 & 0 \\
\hline 1.8 & $\begin{array}{l}\text { Founder of the company has an idea of } \\
\text { active life in pension. }\end{array}$ & 5 & 0,11 & $\begin{array}{l}\text { Research of possible } \\
\text { activities }\end{array}$ & 6 & 1000 \\
\hline 1.9 & $\begin{array}{l}\text { The company is presenting itself as a } \\
\text { family business, focusing on the } \\
\text { advantages of family business (cohesion, } \\
\text { values, quality, know-how...) }\end{array}$ & 2 & 0,11 & $\begin{array}{l}\text { Marketing - the } \\
\text { company has to } \\
\text { present the qualities. }\end{array}$ & 2 & 5000 \\
\hline 1.10 & $\begin{array}{l}\text { Company has a direct binding to the } \\
\text { town/city of the headquarters, it is } \\
\text { keeping good relationship, and it is } \\
\text { advertising itself }\end{array}$ & 1 & 0,1 & $\begin{array}{l}\text { The sponsorhip of } \\
\text { sport activities in } \\
\text { town }\end{array}$ & 1 & 10000 \\
\hline 2.3 & $\begin{array}{l}\text { The company has a strategy plan for the } \\
\text { development including the phase of the } \\
\text { succession }\end{array}$ & 2 & 0,09 & $\begin{array}{l}\text { Successor has to be } \\
\text { mentored regularly } \\
\text { and intensively. }\end{array}$ & 8 & 1000 \\
\hline 2.5 & $\begin{array}{l}\text { The conflicts in the family are strictly } \\
\text { separated from the conflicts in company. }\end{array}$ & 1 & 0,1 & $\begin{array}{l}\text { Hire expert in the } \\
\text { field of conflict } \\
\text { solving }\end{array}$ & 1 & 5000 \\
\hline 2.8 & $\begin{array}{l}\text { The company is offering positions for the } \\
\text { residents of the local town. }\end{array}$ & 2 & 0,1 & $\begin{array}{l}\text { The informations of } \\
\text { the free positions are } \\
\text { presented in local } \\
\text { newspapers. }\end{array}$ & 2 & 500 \\
\hline 3.5 & $\begin{array}{l}\text { In the company, the larger part of the } \\
\text { income is invested back to the company } \\
\text { for the expansion. }\end{array}$ & 4 & 0,11 & $\begin{array}{l}\text { The investment of } \\
\text { the income back to } \\
\text { expansion }\end{array}$ & 1 & 10000 \\
\hline
\end{tabular}

Suppose that we have $C=30000 C Z K$ and $T=30$ hours to invest to improve the vitality. We implement the methodology to Microsoft Excel and we solve the corresponding optimization problem using the extension "Solver". The result of the analysis is the proposal of the optimal time and money investment to specific areas. Using this approach, we are able to improve the resulting benefit from 8,23 to 9,88 . This improvement will cost whole time and money budget. It is necessary to mention that we suppose the linear dependency between the number of investments to specific criteria and the price, for instance, the change of criteria by value by 4 will cost four times the amount of investments as in the case of improvement by one point. The maximum value of the benefit can be achieved by investing $C=$ $179500 \mathrm{CZK}$ and $T=351$ hours. 
In the next analysis, we are interested in the dependency of the achievable optimal value of benefit and the available time budget. We are focusing on how much the larger amount of time investments will improve the vitality of the company. We solve the problem for fixed $C=30000 \mathrm{CZK}$ and various values of time budget, see Fig. 1 (left). This cumulative curve shows how large optimal improvement can be achieved with increasing time budget. It proves that investment of larger amount of time can improve the achievable optimal improvement, however, there exists a point, where we are constrained by money budget and the increasement of invested time does not have any effect. The similar results can be observed with fixed time budget $T=30$ hours and increasing the amount of invested money, see Fig. 1 (right).
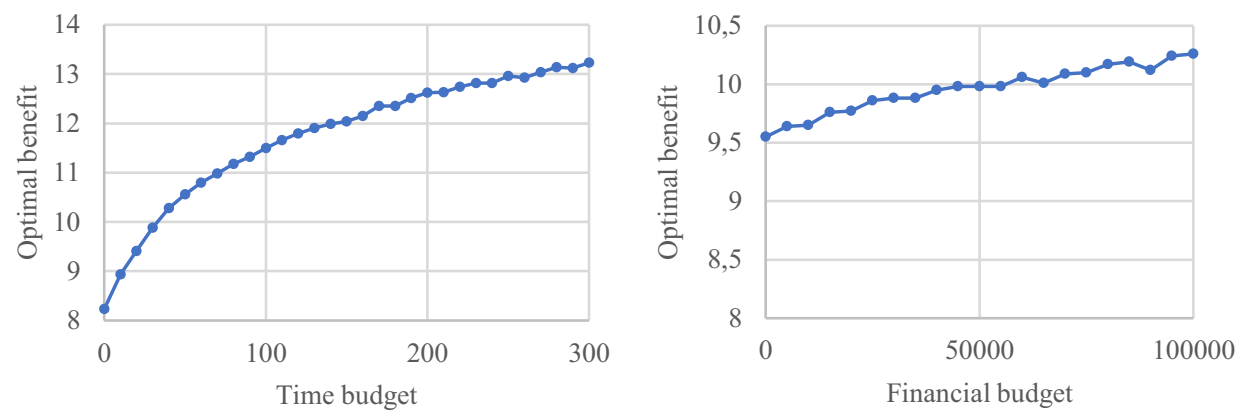

Fig. 1. Optimal benefit with fixed financial budget (left) and fixed time budget (right).

As a last example, let us suppose a situation, when we are changing both of the budget types. To achieve the results, we have implemented a macro in programming language Visual Basic in Microsoft Excel. Our piece of code is running the optimization algorithm "Solver" for different values of the constraints and stores the results. We can observe that with the different values for budgets, we obtain different optimal improvement of the vitality. The results are depicted in the form of graph in Fig. 3 (left).

\subsection{Multicriteria formulation and aggregation}

In this section, we will suppose that our budget is unconstrained. However, we will still try to minimize the overall investments into the optimal improvement of the selected family business. We are looking for the optimal criteria improvement $\hat{y} \in H$, which solves the system of optimization problems

$$
\begin{aligned}
& u(y) \rightarrow \max \\
& c(y) \rightarrow \min \\
& t(y) \rightarrow \min
\end{aligned}
$$

These optimization problems are combined into one aggerated optimization problem (6), i.e.,

$$
\hat{y}=\arg \max g(y), \text { where } g(y)=\beta_{u} u(y)-\beta_{c} c(y)-\beta_{t} t(y)
$$

and $\beta_{u}, \beta_{c}, \beta_{t} \in[0,1], \beta_{u}+\beta_{c}+\beta_{t}=1$ are a priori chosen coefficients of convex combination of individual criteria. The considered constraints are supposed to be the same (13) and (14).

Since the objective function (18) is consisting of terms of different scales, we decided to use the normed prices, i.e., we divided $c_{k}, t_{k}$ by the corresponding maximum values to obtain values from the interval $[0,1]$. 
For the comparison of this methodology with the previously presented approach with constrained budgets, we use the same data. However, instead of introducing the upper bound of budgets, we set the priority of the criteria using $\beta_{c}=\beta_{t}=0,25$ and obviously $\beta_{u}=0,5$.

We solved the corresponding optimization problem in Microsoft Excel. The output of the approach is the design of the optimal investment of time and money to the improvement of the specific areas. Using these values, we are able to increase the final benefit value from 8,23 to 9,76 . This improvement will cost $c(\hat{y})=1500 C Z K$ and $t(\hat{y})=33$ hours.

In our last analysis, we solved the optimization problem for various values of aggregation coefficients $\beta_{c}, \beta_{t}$ and remaining $\beta_{u}=1-\beta_{c}-\beta_{t}$. The results are presented in final graph in Fig. 2 (right). This graph shows, for instance, that in the situation when we do not require the minimization of the financial and time investments $\left(\beta_{c}=\beta_{t}=0\right)$, we obtain the maximal benefit. During the enforcement of the requirement for the minimization of the price, we get the decrease of the corresponding optimal benefit. In the second extreme case, we have $\left(\beta_{c}=\right.$ $\left.\beta_{t}=0,5\right), \beta_{u}=0$ and we are minimizing the investment, but consequently we are not maximizing the benefit at all.
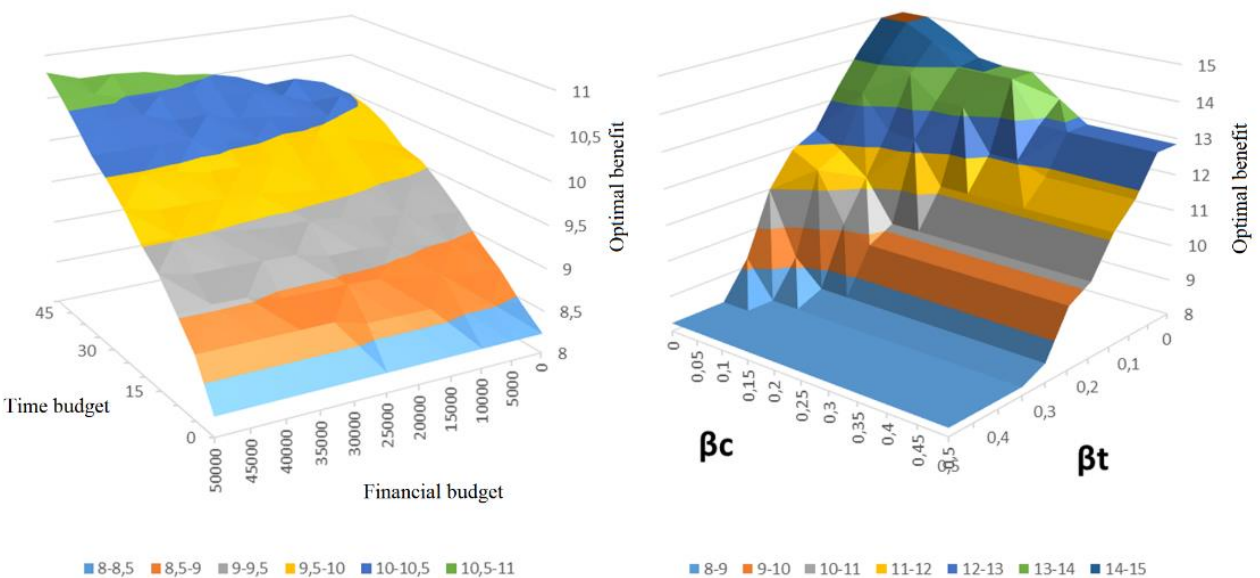

Fig. 2. Maximal achievable benefit for various values of budget upper bound in solution of constrained optimization problem (left) and various values of aggregation coefficients in multicriteria optimization (right).

\section{Conclusion}

In this paper, we present the formulation of mathematical problem for optimal decision in the problem of increasing the vitality of family business. The problem can be solved as an optimization problem with constrained budget or as a multicriteria optimization problem. We demonstrated the efficiency of our approach on the selected business and proposed practical available improvements. The algorithm selects the optimal combination of these options to get the maximal benefit. We solved the problem in popular software Microsoft Excel.

From the solution of the problem, one can define optimal achievable goals, for instance, every activity cost not only money, but also the time. Especially, in the case of family business, the time is scarce commodity and the choice of optimal time spending should be the priority of the development decision making.

From the presented results, it is clear that both of the approaches return similar results of optimal decisions. In the first case, we set non-penetrable upper bound of the budget. This method has clear advantage - the budget will be never exceeded. However, let us imagine the situation, when even the company owner is not able a priori specify the amount of the resources which can be invested to the improvement of vitality. In this case, we are rather 
interested in the amount of the maximal improvement which can be obtained with the minimal investment. In this case, we adopt the multicriteria optimization and present the results in the second part of the paper. However, in this approach, one has to specify the parameters of the aggregation, i.e., specify the priority of optimization. In this case, it is necessary to perform the sensitivity analysis based on the values of aggregation coefficients.

The shortcoming of proposed methodology is the absence of more options for the improvement of specific criteria. In our models, we suppose only one way of the improvement. However, in the case of family business, one way how to deal with problems is to outsource some of the activities - this can be an option of expensive solution, but such a decision can decrease the amount of invested time. The modification to multi-optional model will be the topic of our further research.

Research was supported within the project of the Student Grant Competition at the Faculty of Economics of VSB-TU Ostrava (Czech Republic) SP2020/33.

\section{References}

1. Hlavačka, M., Bek, P. (2018). Rodinné podnikání v moderní době. Liberec: Edice Ekonomické fakulty TU Liberec.

2. Berghoff, H. (2006). The End of Family Business ? The Mittelstand and German Capitalism in Transition, 1949-2000. The Business History Review, 80 (2), 263-295.

3. Koráb, V., Hanzelková, A., Mihalisko, M. (2008). Rodinné podnikání: zpưsoby financování rodinných firem, řizení rodinných podniků, úspěšné předání následnictví. Brno : Computer Press, Praxe podnikatele.

4. Frank, H., Kessler, A., Rusch, T., Suess-Reyes, J., Weismeier-Sammer, D. (2017). Capturing the Familiness of Family Businesses: Development of the Family Influence Familiness Scale (FIFS). Enterpreneurship theory and practice, 41(5), 709-742.

5. Xu, K., Hitt, M.A., Miller, S.R. (2020). The ownership structure contingency in the sequential international entry mode decision process: Family owners and institutional investors in family-dominant versus family-influenced firms. Journal of international business studies, 51(2), 151-171.

6. Romano, C.A., Tanewski, G.A., Smyrnios, K.X. (2001). Capital structure decision making : A model for family business. Journal of Business Venturing, 16(3), 285-310.

7. Ministry of Industry and Trade of Czech republic. (2019, May 13). Rodinné firmy se dočkaly, vláda schválila definici rodinného podnikání [online]. Ministry of Industry and Trade of Czech republic. https:/www.mpo.cz/cz/rozcestnik/pro-media/tiskovezpravy/rodinne-firmy-se-dockaly--vlada-schvalila-definici-rodinneho-podnikani-246105/

8. Machek, O. (2017). Rodinné firmy. Praha: C.H. Beck, Beckova edice ekonomie.

9. Blanco-Mazagatos, V., de Quevedo-Puente, E., Castrillo, L.A. (2007). The Trade-Off Between Financial Resources and Agency Costs in the Family Business: An Exploratory Study. Family Business Review, 20(3), 199-213.

10. Block, J.H. (2011). How to Pay Nonfamily Managers in Large Family Firms: A Principal-Agent Model. Family Business Review, 24(1), 9-27.

11. Allouche, J., Amann, B., Jaussaud, J., Kurashina, T. (2008). The Impact of Family Control on the Performance and Financial Characteristics of Family Versus Nonfamily Business in Japan: A Matched-Pair Investigation. Family Business Review, 21(4), 315330. 
12. Rod, A. (2012). Likertovo škálování. E-LOGOS Electronic Journal for Philosophy, 19 , $1-13$.

13. Likert, R. (1932). A Technique for the Measurement of Attitudes. Archives of Psychology, 22(140), 1-55.

14. Sirbiladze, G., Khutsishvili, I., Ghvaberidze, B. (2014). Multistage decision-making fuzzy methodology for optimal investments based on experts' evaluations. European Journal of Operational Research, 232(1), 169-177.

15. Lee, J. (2006). Impact of Family Relationships on Attitudes of the Second Generation in Family Business. Family Business Review, 19(3), 175-191.

16. Alvarez, J.M.S, Palma-Ruiz, J.M., Leitão, J.C.C. (2019). Entrepreneurship and Family Business Vitality: Surviving and Flourishing in the Long Term. Springer International Publishing.

17. Petru, N., Havlicek, K., Tomaskova, A. (2018) Comparison of marketing vitality of family and non-family companies doing business in Czech Republic. Economics \& Sociology, 11(2), 138-156.

18. Collective of authors (2017). Typologie a hodnocení vitality rodinného podnikání. Liberec: Edice Ekonomické fakulty TU Liberec. ISBN: 978-80-7494-352-2.

19. Brožová, H., Houška, M., Šubrt, T. (2014). Modely pro vícekriteriální rozhodování. Prague: Česká zemědělská univerzita, Provozně ekonomická fakulta.

20. Ehrgott, M. (2005). Multicriteria Optimization. Springer.

21. Fiala, P., Jablonský, J., Maňas, M. (1997). Vícekriteriální rozhodování. Praha: Vysoká škola ekonomická. 